\title{
Biological and biochemical properties in evaluation of forest soil quality
}

\author{
Ewa Błońska, Jarosław Lasota \\ University of Agriculture in Krakow, Faculty of Forestry, Department of Forest Soil Science, 29 Listopada 46, \\ 31-425 Kraków, Poland, phone: +48 12 6625031, e-mail: eblonska@ar.krakow.pl
}

\begin{abstract}
The aim of this study was to assess the possibility of using biological and biochemical parameters in the evaluation of forest soil quality and changes caused by land use. The study attempted to determine a relationship between the enzymatic activity of soil, the number of earthworms and soil physico-chemical properties. The study was carried out in central Poland in adjoining Forest Districts (Przedbórz and Smardzewice). In soil samples taken from 12 research plots, basic physico-chemical properties, enzyme activity (dehydrogenase, urease) and density and biomass of earthworms were examined. Enzyme activity showed a large diversity within the forest site types studied. The correlations between the activity of the enzymes studied and $\mathrm{C} / \mathrm{N}$ ratio indicated considerable importance of these enzymes in metabolism of essential elements of organic matter of forest soils. Urease and dehydrogenase activity and earthworm number showed susceptibility to soil $\mathrm{pH}$, which confirmed relationships between enzyme activity and abundance of earthworms and soil $\mathrm{pH}$ in $\mathrm{H}_{2} \mathrm{O}$ and $\mathrm{KCl}$.
\end{abstract}

\section{KeY WORDS}

earthworms, enzyme activity, forest soils, soil quality

\section{INTRODUCTION}

Soil in forest environment is a crucial element for the existence of living organisms, as well as wood production and maintaining environmental quality (Fisher and Binkley 2000). Production capacity of soil depends on its quality, and consequently research of that soil properties has been the main subject of interest for soil scientists. Franzluebbers and Haney (2006) are in favor of using soil physical, chemical and biological properties, which play an important role in energy production, supplying plants with nutrients and circulation and accumulation of these elements in the soil resources. Soil enzyme activities have been used as sensors in studies on the influence of soil treatments on microbial activity and soil fertility (Chen 2003) and they have been reported to be greatly affected by changes in soil management practices (Floch et al. 2009). Dehydrogenase activity is considered to be an indicator of oxidative metabolism in soils, and consequently - of the microbial activity (Trevors 1984). Dehydrogenase represents enzymes, which give information about the state of environment. Dehydrogenase activity can be used to assess soil quality, the impact of soil usage on its quality as well as to evaluate a degree of regeneration in degraded soils (Gil-Sotres et al. 2005). Soil urease are one of the most important 
enzymes involved in soil organic matter mineralization, they release $\mathrm{N}-\mathrm{NH}_{4}{ }^{+}$through urea hydrolysis and are essential in the chain of hydrolysis of amino compounds, which are supplied to soil from plants, and to a lesser extent from animals and microorganisms (Salazar et al. 2011). In addition, this enzyme is a part of microbial products that can be accumulated in cell of microorganisms because they are highly resistant to environmental degradation (Zantua and Bremner 1977). Urease activity according to many authors should be used as an indicator of soil quality and changes in soil (Gil-Sotres et al. 2005). According to Bardgett (2002), soil organisms allows to evaluate the efficiency of ecosystem, namely changes in their diversity and abundance. Soil organisms have gained the title of a biological indicator of soil quality. Ponge et al. (2003) and Broma et al. (2009) propose the use of Collembola as indicators of environmental changes and good biomonitor of soils. Birkás et al. (2004) identified earthworms as an important biological indicator in soil quality assessment. In soils where cultivation was applied and deteriorated their stability, the authors found fewer earthworms than in those undisturbed or not cultivated with the use of methods intrusive for soil stability.

The aim of this study was to assess the possibility of using biological and biochemical parameters in evaluations of forest soils and changes caused by land use. Up to date, biological and biochemical properties have been rarely used in assessing forest soil quality than physical and chemical properties (Januszek 1999; Januszek et al. 2006). The study attempted to determine a relationship between the enzymatic activity, the number of earthworms and soil physico-chemical properties. In addition, attempts were undertaken to establish the relations between vegetation and soil properties as well as density and biomass of earthworms.

\section{Material ANd Methods}

The study was carried out in September 2011, in two adjacent Forest Districts: Przedbórz and Smardzewice (central Poland). There were chosen 12 research plots of which 9 were covered with tree vegetation and 3 plots were after passing windfall (without vegetation). The type of forest site within the plots was determined based on soil and vegetation (if possible). Three research areas represented fresh broadleaf forest with Cambic Brunic Arenosol and Cambisol and three plots - wet broadleaf forest with Stagnosol, Gleysol and Histosol. Six areas represented fresh mixed broadleaf forest with Brunic Arenosol and Stagnosol. Three of the surveyed areas (No. 10, 11, 12) were surfaces after following the windfall, without tree vegetation and they represented fresh broadleaf forest site and fresh mixed broadleaf forest.

Tab. 1. Characteristics of research plots

\begin{tabular}{|c|l|l|l|}
\hline $\begin{array}{c}\text { No. } \\
\text { of } \\
\text { plot }\end{array}$ & \multicolumn{1}{|c|}{$\begin{array}{c}\text { Type } \\
\text { of soil }\end{array}$} & \multicolumn{1}{|c|}{ Type of forest site } & \multicolumn{1}{|c|}{$\begin{array}{c}\text { Species } \\
\text { compositions }\end{array}$} \\
\hline 1 & Stagnosol & wet broadleaf & $6 \mathrm{~Gb} 4 \mathrm{OlBkJ} J \mathrm{Jd}$ \\
\hline 2 & Stagnosol & fresh mixed broadleaf & $6 \mathrm{Jd} 2 \mathrm{Brz} 1 \mathrm{Ol1Sw}$ \\
\hline 3 & Gleysol & wet broadleaf & $6 \mathrm{~Gb} 4 \mathrm{Ol}$ \\
\hline 4 & Histosol & wet broadleaf & $6 \mathrm{O} 13 \mathrm{Js} 1 \mathrm{~Gb} 1 \mathrm{Kl}$ \\
\hline 5 & Arenosol & fresh mixed broadleaf & 10Db \\
\hline 6 & Arenosol & fresh mixed broadleaf & $6 \mathrm{Jd} 4 \mathrm{Db}$ \\
\hline 7 & Arenosol & fresh mixed broadleaf & 9Jd1Gb \\
\hline 8 & Cambisol & fresh broadleaf & 4So3Db2Bk1Gb \\
\hline 9 & Arenosol & fresh broadleaf & 7Db2So1Gb \\
\hline 10 & Cambisol & fresh broadleaf & plots after windfall \\
\hline 11 & Arenosol & fresh mixed broadleaf & plots after windfall \\
\hline 12 & Arenosol & fresh mixed broadleaf & plots after windfall \\
\hline
\end{tabular}

Gb- hornbeam, Ol - alder, Bk - beech, Js - ash, Jd - fir, $\mathrm{Brz}$ - birch, Sw - spruce, $\mathrm{Kl}$ - maple, $\mathrm{Db}$ - oak, So - pine.

At each sample plot, a detailed examination of soil profile was carried out, soil samples were taken from each genetic horizon in order to perform further analyses of soil properties ( $\mathrm{pH}$ in $\mathrm{H}_{2} \mathrm{O}$ and $1 \mathrm{M} \mathrm{KCl}$ solution; hydrolytic acidity; total nitrogen and carbon content followed by determination of $\mathrm{C} / \mathrm{N}$ ratio; granulometric composition). The soil for determining enzyme activity was collected after removal of the litter layer. In all cases, soil samples were collected from 8 sub-stands of the upper soil horizon $(0-10 \mathrm{~cm})$, pooled in the field, transported to the laboratory and then sieved through a $2 \mathrm{~mm}$ sieve. The samples were stored at $4^{\circ} \mathrm{C}$ until the analysis.

Soil granulometric composition was determined by means of the aerometric method, $\mathrm{pH}$ in water and $1 \mathrm{M}$ $\mathrm{KCl}$ - with potentiometric measurements, total nitrogen and organic carbon - with LECO apparatus, with 
calculation of $\mathrm{C} / \mathrm{N}$ ratio, alkaline cations content in $1 \mathrm{M}$ ammonium acetate with calculation of the degree of base saturation ( $\mathrm{V} \%$ ), and available - phosphorus with the Bray-Kurtz method. Bulk density was determined mechanically using Kopecky cylinders.

Dehydrogenase activity was determined using Lenhard's method consistent with the Casida procedure, expressing their activity in Triphenyl formazan milligrams (TPF) for $100 \mathrm{~g}$ of soil within 24 hours (Alef and Nannipieri 1995). Urease activity was determined with Tabatabai and Bremner's method (1972) (Alef and Nannipieri 1995), expressing enzyme activity in $\mu \mathrm{g} \mathrm{N}-\mathrm{NH}_{4}$ for $1 \mathrm{~g}$ of soil during 2 hours.

In order to determine earthworm density two methods were used: a method of manual sorting and formalin extraction method (Clapperton et al. 2007). Determination of earthworms were made in five replicates with the calculation of density and biomass. The earthworms were classified in three ecological categories (epigeic, endgeic and anecic).

Statistical analyses were performed using Statistica 9 software Differences between mean values from two samples were tested with the Kruskal-Wallis test. We also calculated Pearson's correlation coefficients between soil physico-chemical properties, density of earthworms, biomass of earthworms and enzyme activities.

\section{Results}

Dehydrogenase activity in the soils tested was in a range from 2.19 to $91.26 \mathrm{mg} \mathrm{TPF} / 100 \mathrm{~g}$ soil/24 h (tab. 2). Average dehydrogenase activity was $18.57 \mathrm{mg} \mathrm{TPF} / \mathrm{kg} / 24 \mathrm{~h}$. The highest dehydrogenase activity was observed on the plot number 4 with Histosols. At the same time, the soil on this plot was characteristic of high: $\mathrm{pH}(\mathrm{pH} 6.7$ $\left.\mathrm{H}_{2} \mathrm{O}\right)$, sum of alkaline cations $(36.5 \mathrm{cmol}(+) / \mathrm{kg})$ and base saturation (83\%) (tab. 2). The lowest dehydrogenase activity was observed on the plot number 2 with Stagnosols, which showed one of the lowest $\mathrm{pH}$ values (tab. 2).

Urease activity in the soil was in a range from 0.69 to $64.20 \mathrm{mg} \mathrm{N}-\mathrm{NH}_{4}{ }^{+} / \mathrm{g} / 2 \mathrm{~h}$ (tab. 2). The highest urease activity was observed on the plot No. 1, and the lowest on the plot No. 10. The soil on the plot 1 was characterized by one of the highest values of $\mathrm{pH}\left(\mathrm{pH} 5.8 \mathrm{H}_{2} \mathrm{O}\right)$ and carbon content (4.7\%), while the plot 10 showed low: $\mathrm{pH}$

Tab. 2. Enzyme activity and basic properties of soils tested

\begin{tabular}{|c|c|c|c|c|c|c|c|c|c|c|c|c|c|}
\hline \multirow{2}{*}{$\begin{array}{l}\text { No. } \\
\text { of } \\
\text { plot }\end{array}$} & $\begin{array}{c}\text { Dehydrogenase } \\
\text { activity }\end{array}$ & $\begin{array}{l}\text { Urease } \\
\text { activity }\end{array}$ & $\mathrm{pH}$ & $\mathrm{pH}$ & $\mathrm{C}$ & $\mathrm{N}$ & \multirow{2}{*}{$\mathrm{C} / \mathrm{N}$} & $\mathrm{Y}$ & $\mathrm{S}$ & \multirow{2}{*}{$\begin{array}{l}\mathrm{V} \\
\%\end{array}$} & \multirow{2}{*}{$\begin{array}{c}\text { Texture } \\
\text { classes } \\
\text { PSSS 2008 }\end{array}$} & \multirow{2}{*}{\begin{tabular}{|c|}
$\begin{array}{c}\text { Density } \\
\text { of earthworms }\end{array}$ \\
no. $/ \mathrm{m}^{2}$ \\
\end{tabular}} & \multirow{2}{*}{\begin{tabular}{|c|c|}
$\begin{array}{c}\text { Biomass } \\
\text { of earthworms }\end{array}$ \\
$\mathrm{g} / \mathrm{m}^{2}$
\end{tabular}} \\
\hline & $\begin{array}{l}\mathrm{mg} \mathrm{TPF} \\
/ \mathrm{kg} / 24 \mathrm{~h}\end{array}$ & $\begin{array}{l}\mathrm{N}-\mathrm{NH}_{4}^{+} \\
/ \mathrm{g} / 2 \mathrm{~h}\end{array}$ & $\mathrm{H}_{2} \mathrm{O}$ & $\mathrm{KCl}$ & \multicolumn{2}{|c|}{$\%$} & & \multicolumn{2}{|c|}{$\begin{array}{c}\mathrm{cmol}(+) \\
/ \mathrm{kg}\end{array}$} & & & & \\
\hline 1 & 30.34 & 64.17 & 5.8 & 5.2 & 4.7 & 0.4 & 12 & 5.3 & 6.8 & 56 & $\mathrm{pg}$ & 19 & 8 \\
\hline 2 & 2.20 & 6.70 & 4.1 & 3.0 & 3.2 & 2.0 & 16 & 77.6 & 3.9 & 5 & $\mathrm{gl}$ & 0 & 0 \\
\hline 3 & 43.22 & 38.53 & 6.4 & 5.6 & 4.0 & 0.4 & 10 & \begin{tabular}{|l|}
16.0 \\
\end{tabular} & 29.8 & 66 & pg & 13 & 5 \\
\hline 4 & 91.26 & 62.54 & 6.7 & 6.0 & 6.6 & 0.6 & 11 & 7.3 & 36.5 & 83 & $\begin{array}{l}\text { organic } \\
\text { horizon }\end{array}$ & 10 & 6 \\
\hline 5 & 8.49 & 16.66 & 4.3 & 3.4 & 2.8 & 0.2 & 17 & 9.7 & 1.0 & 10 & pg & 0 & 0 \\
\hline 6 & 5.89 & 18.46 & 3.7 & 2.9 & 2.1 & 0.2 & 14 & 12.6 & 0.5 & 4 & gp & 0 & 0 \\
\hline 7 & 2.81 & 13.86 & 4.0 & 3.2 & 6.3 & 0.4 & 17 & 20.7 & 2.3 & 10 & pg & 3 & 2 \\
\hline 8 & 5.97 & 17.07 & 4.6 & 3.5 & 2.5 & 0.2 & 17 & 11.9 & 1.2 & 9 & pg & 6 & 3 \\
\hline 9 & 17.15 & 38.84 & 4.4 & 3.6 & 1.5 & 0.2 & 10 & 33.1 & 3.0 & 8 & pg & 6 & 3 \\
\hline 10 & 3.81 & 0.69 & 4.2 & 3.4 & 4.9 & 0.4 & 14 & 8.1 & 0.7 & 8 & $\mathrm{pg}$ & 0 & 0 \\
\hline 11 & 3.57 & 2.80 & 3.9 & 3.1 & 4.7 & 0.3 & 15 & 11.9 & 1.6 & 12 & $\mathrm{pg}$ & 0 & 0 \\
\hline 12 & 8.11 & 7.35 & 3.9 & 3.4 & 2.0 & 0.2 & 14 & 24.2 & 1.7 & 7 & psg & 0 & 0 \\
\hline
\end{tabular}

Y - hydrolytic acidity, S - sum of exchangeable bases, V - base saturation, psg - sand, pg - loamy sand, gp - sandy loam, gl - loam. 
( $\left.\mathrm{pH} 4.2 \mathrm{H}_{2} \mathrm{O}\right)$, alkaline cation amount $(0.66 \mathrm{cmol}(+) / \mathrm{kg})$ and base saturation (7\%).

The highest enzyme activity and density of earthworms were associated with wet broadleaf forest site on plots 1, 3 and 4, where the broadleaf forest with hornbeam, alder and ash prevailed. Areas dominated by coniferous species on the fresh mixed broadleaf site (plot 2 and 7) had the lowest activity of dehydrogenases and urease. The low activity of enzymes and the lack of earthworm in soil was showed in the plots without tree vegetation after windfall. Urease activity was similar to the activity of dehydrogenases.

The presence of earthworms was observed on 6 plots. Earthworm density varied from 3 to 19 specimens $/ \mathrm{m}^{2}$ and their biomass from 2 to $8 \mathrm{~g} / \mathrm{m}^{2}$. The highest density and biomass of earthworms was associated with soils with high $\mathrm{pH}$, high $\mathrm{C}$ content and high enzymatic activity. According to the division of trophic groups, endgeic species dominated - colonizing the mineral soil horizon. During the study, there were noted no species digging vertical hallways and epigeic species - living in litter.

The Kruskal-Wallis test showed statistically significant differences in enzyme activity between different forest sites (tab. 3). Dehydrogenase activity was positively correlated with $\mathrm{pH}$ in $\mathrm{H}_{2} \mathrm{O}$ and $\mathrm{KCl}(0.80$ and 0.88 ) as well as the sum of base cations and base saturation (0.93 and 0.93). A negative correlation was observed between the activity of dehydrogenases and $\mathrm{C} / \mathrm{N}$ ratio (-0.65). Urease activity, likewise dehydrogenase activity was correlated with $\mathrm{pH}$ in $\mathrm{H}_{2} \mathrm{O}$ and $\mathrm{KCl}$ (0.82 and 0.83), but not as much with the sum of the alkaline cations and base saturation (0.67 and 0.84). A negative correlation was observed between the activity of urease and $\mathrm{C} / \mathrm{N}$ ratio $(-0.68)$. The activities of both dehydrogenase and urease were positively correlated with the density and biomass of earthworms (tab. 4).

Tab. 3. Basic statistics and Kruskal-Wallis test results on enzyme activity in different forest sites

\begin{tabular}{|c|c|c|c|c|c|c|}
\hline \multirow{2}{*}{ 胥: } & \multirow{2}{*}{ 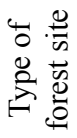 } & \multirow{2}{*}{$\begin{array}{l}0 \\
000 \\
\frac{\pi}{0} \\
\frac{1}{4}\end{array}$} & \multirow{2}{*}{ 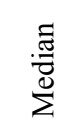 } & \multirow{2}{*}{ 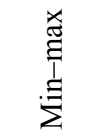 } & \multicolumn{2}{|c|}{$\begin{array}{c}\text { Kruskal-Wallis } \\
\text { test }\end{array}$} \\
\hline & & & & & $\mathrm{H}$ & p-value \\
\hline \multirow{3}{*}{$\begin{array}{l}\text { Dehydro- } \\
\text { genase } \\
\text { activity }\end{array}$} & 1 & 39.58 & 30.34 & $\begin{array}{l}15.97- \\
-91.26\end{array}$ & \multirow{3}{*}{8.1217} & \multirow{3}{*}{0.0172} \\
\hline & 2 & 4.84 & 4.35 & $\begin{array}{l}2.20- \\
-8.49\end{array}$ & & \\
\hline & 3 & 5.15 & 3.81 & $\begin{array}{l}3.57- \\
-8.11\end{array}$ & & \\
\hline \multirow{3}{*}{$\begin{array}{l}\text { Urease } \\
\text { activity }\end{array}$} & 1 & 44.23 & 38.84 & $\begin{array}{l}17.07- \\
-64.17\end{array}$ & \multirow{3}{*}{8.5025} & \multirow{3}{*}{0.0142} \\
\hline & 2 & 13.92 & 15.26 & $\begin{array}{c}6.70- \\
-18.46\end{array}$ & & \\
\hline & 3 & 3.61 & 2.8 & $\begin{array}{l}0.69- \\
-7.35\end{array}$ & & \\
\hline
\end{tabular}

1 - broadleaf forest sites; 2 - mixed broadleaf forest sites; 3 - sites after windfall.

\section{Discussion OF RESULTS}

The relationship between an individual biochemical property and the total microbial activity is not always obvious, especially in the case of complex systems like soils, where microorganisms and processes involved in degradation of organic compounds are highly diverse (Nannipieri et al. 1990). Enzyme activity can be affected by a number of natural and anthropogenic factors. For example, soil temperature and moisture content

Tab. 4. Correlation coefficients between enzyme activity and soil physico-chemical properties, density and biomass of earthworms

\begin{tabular}{|c|c|c|c|c|c|c|c|c|c|c|c|c|}
\hline & \multirow{2}{*}{$\begin{array}{c}\text { Dehydrogenase } \\
\text { activity }\end{array}$} & \multirow{2}{*}{$\begin{array}{l}\text { Urease } \\
\text { activity }\end{array}$} & \multirow{2}{*}{$\begin{array}{c}\mathrm{pH} \\
\text { in } \\
\mathrm{H}_{2} \mathrm{O}\end{array}$} & \multirow{2}{*}{$\begin{array}{c}\mathrm{pH} \\
\text { in } \\
\mathrm{KCl}\end{array}$} & \multirow{2}{*}{$\begin{array}{c}\text { Organic } \\
\mathrm{C}\end{array}$} & \multirow{2}{*}{$\begin{array}{c}\text { Total } \\
\mathrm{N}\end{array}$} & \multirow[t]{2}{*}{$\mathrm{C} / \mathrm{N}$} & \multirow[t]{2}{*}{$\mathrm{Y}$} & \multirow[t]{2}{*}{$\mathrm{S}$} & \multirow[t]{2}{*}{ V } & $\begin{array}{c}\text { Density of } \\
\text { earthworms }\end{array}$ & $\begin{array}{l}\text { Biomass of } \\
\text { earthworms }\end{array}$ \\
\hline & & & & & & & & & & & no. $/ \mathrm{m}^{2}$ & $\mathrm{~g} / \mathrm{m}^{2}$ \\
\hline $\begin{array}{l}\text { Dehydro- } \\
\text { genase } \\
\text { activity }\end{array}$ & 1.00 & 0.81 & 0.86 & 0.88 & -0.10 & 0.03 & -0.65 & -0.28 & 0.93 & 0.93 & 0.60 & 0.70 \\
\hline $\begin{array}{l}\text { Urease } \\
\text { activity }\end{array}$ & 0.81 & 1.00 & 0.82 & 0.83 & -0.19 & -0.08 & -0.68 & -0.29 & 0.67 & 0.84 & 0.88 & 0.94 \\
\hline
\end{tabular}

Y - hydrolytic acidity, S - sum of exchangeable bases, V - base saturation. 
(Fioretto et al. 2000), pH (DeForest et al. 2012), plant litter quality (Waldrop and Zak 2006) and C and nutrient availability can all influence enzyme activity. Soil temperature and moisture content changes are probably largely responsible for seasonal variation in enzymes activity (Boerner et al. 2005).

The results obtained in this study confirm the above statements. On the test plots, different activities of dehydrogenases and urease were recorded within the forest area covered with trees when compared with those observed inside the windfall area, where entirely different management activities were conducted. Simultaneously, the plots tested were characteristic of diverse species composition. This had direct impact on quantity and quality of organic matter supply to soil, and resultant enzyme activities. The highest activity of dehydrogenases as well as urease was observed on plots with tree stands with prevailing deciduous species, such as hornbeam, alder and ash. Lower enzyme activity was observed on the area with the dominance of fir, and the lowest - on the area without tree stands (after windfall).

Salazar et al. (2011) noted correlations between soil biochemical and soil microbiological variables, which showed that the three different forest management practices also had a strong effect on soil function conditions. Soil organic matter is considered an important indicator of soil quality due to its nutrient sink character and being a source that can enhance soil physical and chemical properties and promote biological activity (Jimenez et al. 2002). Quilchano and Maranón (2002) reported that differences in plant species composition and soil properties could be responsible for variability in dehydrogenase. The authors found that this enzyme activity was positively and significantly correlated with soil pH but not with total soil C and N. The above statement supports the results of this study, i.e. the obtained correlations between the activity of dehydrogenase as well as urease and soil physico-chemical properties.

The factors which determine distribution of earthworms in soil are: soil $\mathrm{pH}$, mechanical composition, humidity and availability of food. Earthworms do not tolerate acidic soils, especially dry soils. They develop best in the medium-heavy soil humus, where $\mathrm{pH}$ is in a range from 6.0 to 7.0. Earthworms found such conditions in the soils of fresh and wet broadleaf forest with the dominance of broadleaf species and mull humus type. On the windfall area, there was no presence of earthworms noted, because these were over dried sites, not conducive to the development of plants and earthworms. Results of Palm et al. (2013) showed that management practices (i.e. disturbances), topography, soil conditions were the most relevant predictors for spatial distribution of all three functional groups of earthworms. Epigeics are controlled by topographic features, and endogeics - by soil parameters. Endgeic species dominated in the studied soils. During the study, there were noted neither epigeic nor anecic earthworm species.

The study indicated a high correlation between enzyme activity and the density and biomass of earthworms. The earthworms have a large impact on physical and chemical soil condition (Nachtergale et al. 2002). They contribute to rapid circulation of elements in nature because they stimulate the growth of microorganisms and organic debris are prepared for enzymatic degradation, and thus stimulate enzyme activity. The effect of earthworms on soil hydrolases (protease, urease, invertase, and alkaline phosphatase) and dehydrogenase activities was investigated by Tao et al. (2009). Their results showed that the presence of earthworms strongly affected soil enzymes' activities.

\section{Conclusions}

1. Enzyme activity showed considerable diversity among the studied types of forest sites.

2. The correlations observed between the activity of enzymes and $\mathrm{C} / \mathrm{N}$ ratio indicated significant importance of enzymes in metabolism of essential elements in organic matter of forest soils.

3. Enzyme activity depends on soil physico-chemical properties.

4. Urease and dehydrogenase activity and the number of earthworms showed susceptibility to soil $\mathrm{pH}$, which was confirmed by the correlation between the activity of the enzymes and abundance of earthworms and $\mathrm{pH}$ in $\mathrm{H}_{2} \mathrm{O}$ and $\mathrm{KCl}$.

5. Procedures related to cleanup of trees after windfall breached soil natural structure and disrupted biological balance of soil environment as evidenced by a decline in earthworm biomass and enzyme activity. 


\section{References}

Alef K., Nannipieri P. 1995. Enzyme activities. In: Methods in applied Soil Microbiology and Biochemistry (eds.: K. Alef, P. Nannipieri), Academic Press, London, New York, San Francisco.

Bardgett E.D. 2002. Causes and consequences of biological diversity in soil. Zoology, 105, 367- 374.

Birkás M., Jolánkai M., Gyuricza C., Percze A. 2004. Tillage effects on compaction, earthworms and other soil quality indicators in Hungary. Soil and Tillage Research, 78, 185- 196.

Boerner R.E., Brinkman J.A., Smith A. 2005. Seasonal variations in enzyme activity and organic carbon in soil of a burned and unburned hardwood forest. Soil Biology and Biochemistry, 37, 1419-1426.

Broma M., Rajfur M., Kłos A., Duczmal K., Wacławek M. 2009. Use of earthworms to assess soil contamination with heavy metals. Chemistry, Didactics, Ecology, Meteorology, 14, 1-2.

Chen H.J. 2003. Phosphatase activity and P fractions in soils of an 18-year-old Chinese fir (Cunninghamia lanceolata) plantation. Forest Ecology and Management, 178, 301-310.

Clapperton M.J., Baker G.H., Fox C.A. 2007. Earthworms. In: Soil Sampling and Methods of Analysis (eds.: M.R. Carter, E.G. Gregorich), Canadian Society of Soil Science, 427-444.

DeForest J.L., Becker J., Burke D.J., Elliott H.L., Smemo K.A. 2012. Soil microbial responses to phosphorus addition and $\mathrm{pH}$ manipulation in acidic temperate deciduous forests. Biogeochemistry, 109, 189-202.

Fioretto A., Papa S., Curcio E., Sorrentino G., Fuggi A. 2000. Enzyme dynamics on decomposing leaf litter of Cistus incanus and Myrtus communis in a Mediterranean ecosystem. Soil Biology and Biochemistry, 32, 1847-1855.

Fisher R.F., Binkley D. 2000. Ecology and management of forest soils. John Wiley and Sons, New York.

Floch C., Capowiez Y., Criquet S. 2009. Enzyme activities in apple orchard agroecosystems: How are they affected by management strategy and soil properties. Soil Biology and Biochemistry, 41, 61-68.

Franzluebbers A.J., Haney R.L. 2006. Assessing soil quality in organic agriculture. Critical Issue Report. The Organic Center.
Gil-Sotres F., Trasar-Cepeda C., Leiros M.C., Seoane S. 2005. Different approaches to evaluating soil quality using biochemical properties. Soil Biology and Biochemistry, 37, 877-887.

Januszek K. 1999. The enzymatic activity of selected forest soils of southern Polish in the light of field studies and laboratory (in Polish with English summary). Zeszyty Naukowe AR Kraków, Rozprawy, 250, 5-132.

Januszek K., Lasota J., Fiślak A. 2006. The Evaluation of quality of soils of the Carpathian lime tree forest and beech forests on the basis of some chemical and biochemical properties. Acta Scientarium Polonorum, Silvarum Colendarum Ratio et Industria Lignaria, 5 (2), 71-87.

Jimenez M.P., De La Horra A.M., Pruzzo L., Palma R.M. 2002. Soil quality: a new index based on microbiological and biochemical parameters. Biology Fertility of Soils, 35, 302-306.

Nachtergale L., Ghekiere K., Schrijver A., Muys B., Luyssaert S., Lust N. 2002. Earthworm biomass and species diversity in windthrow sites of a temperate lowland forest. Pedobiologia, 46, 440-451.

Nannipieri P., Grego S., Ceccanti B. 1990. Ecological significance of biological activity. In: Soil Biochemistry Vol. 6 (eds.: J.M. Bollag, G. Stotzky), Marcel Dekker Inc., New York, 293-355.

Palm J., Schaik N., Schröder B. 2013. Modelling distribution patterns of anecic, epigeic and endogeic earthworms at catchment-scale in agro-ecosystems. Pedobiologia, 56(1), 23-31.

Ponge J.F., Gillet S., Dubs F., Fedoroff E., Haese L., Sousa J.P., Lavelle P. 2003. Collembolan communities as bioindicators of land use intensification. Soil Biology and Biochemistry, 35, 813-826.

Quilchano C., Maranón T. 2002. Dehydrogenase activity in Mediterranean forest soils. Biology and Fertility of Soils, 35, 102-107.

Salazar S., Sánchez L.E., Alvarez J., Valverde A., Galindo P., Igual J.M., Peix A., Santa-Regina I. 2011. Correlation among soil enzyme activities under different forest system management practices. Ecological Engineering, 37, 1123-1131.

Tao J., Griffiths B., Zhang S., Chen X., Liu M., Hu F., Li H. 2009. Effects of earthworms on soil enzyme 
activity in an organic residue amended rice-wheat rotation agro-ecosystem. Applied Soil Ecology, 42, 221-226.

Trevors J.T. 1984. Dehydrogenase activity in soil: a comparison between the INT and TTC assay. Soil Biology and Biochemistry, 16, 673-674.
Waldrop M.P., Zak D.R. 2006. Response of oxidative enzyme activities to nitrogen deposition affects soil concentrations of dissolved organic carbon. Ecosystems, 9, 921-933.

Zantua M., Bremner J.M. 1977. Stability of urease in soil. Soil Biology and Biochemistry, 9, 135-140. 